\title{
EDUCATION AS AN IMPORTANT FACTOR OF THE SITUATION OF YOUNG PEOPLE IN THE LABOR MARKET
}

\author{
[Vzdelanie ako dôležitý faktor postavenia mladých l’udí na trhu práce]
}

\author{
Tímea Kolláriková ${ }^{1}$ \\ ${ }^{1}$ Ekonomická univerzita v Bratislave, Národohospodárska fakulta, Dolnozemská cesta 1, 85235 Bratislava 5, \\ e-mail: timea.kollarikova@gmail.com
}

\begin{abstract}
The article focuses on the issue of education relating to employability of young people in the labor market, particularly in the Slovak Republic. It aims to analyze the current position of young people in the Slovak labor market using the method of comparison of unemployment rate with other countries of the European Union. In Slovakia, the situation of young people in the labor market is developing with negative trend, thus resulting in their prolonged high unemployment and the long duration of the transition from education to the labor market. The school system should be flexible and should also provide young people with some security. The paper sets out the main areas in improving formal education, based on the proposals for action of the European Commission. From the recommendations /May 2013/ for the Slovak Republic result the following proposals: to deal with the unfavorable situation of young through guarantees for young people, to take action to improve learning outcomes, to strengthen the provision of practical training directly in companies in vocational education and training, to support the effective transfer of knowledge by encouraging cooperation between universities, research community and the business sector.
\end{abstract}

Keywords: education, employability, labor market, unemployment.

JEL classification: E24, J01

Doručeno redakci: 26.11.2013; Recenzováno: 13.4.2014; 13.5.2014; Schváleno k publikování: 23.9.2014

\section{Úvod}

L'udský kapitál je forma kapitálu, ktorý vlastnia l'udia, tým že disponujú určitým súborom schopností, zručností, vedomostí, znalostí a múdrost'ou. V podmienkach dnešnej znalostnej spoločnosti ide o kl'účový faktor k dosahovaniu konkurencieschopnosti a rozvoja ekonomík. Vzdelávanie je preto nesmierne dôležitou súčast'ou celého procesu rozvoja l'udského kapitálu obzvlášt' u mladých l'udí, ktorí predstavujú vel'ký potenciál jednotlivých ekonomík.

Pre európske trhy práce je stále charakteristická priepast' medzi požadovanými a ponúkanými zručnost’ami. Do popredia sa dostáva potreba neustálej aktualizácie potrebných zručností v záujme zamestnatel'nosti na podporu rastu a pracovných miest, čo by malo viest' k riešeniu pretrvávajúcej nezamestnanosti mladých l'udí a pomalého ekonomického rastu. Podl'a Európskej komisie sa vytvorí do roku 2020 o 20\% viac pracovných miest vyžadujúcich vyššiu úroveň zručností. V tejto súvislosti Komisia taktiež apeluje na podporenie prierezových zručností.(Európska komisia, 2012a)

Ciel'om príspevku je poukázat' na postavenie mladých l'udí na trhu práce v SR a zdôraznit' význam formálneho i neformálneho vzdelávania pri uplatňovaní mladých l'udí na trhu práce. Zvlášt' dat' do pozornosti možné riešenia, ktoré vychádzajú z politiky zamestnanosti Európskej únie a taktiež SR. Prvá kapitola je venovaná prehl'adu teoretických a empirických prístupov vzt'ahu vzdelania a zamestnanosti, resp. nezamestnanosti. Druhá kapitola sa zameriava na vývoj situácie mladých l’udí na slovenskom trhu práce. Tretia kapitola popisuje význam vzdelávania pri uplatňovaní mladých l’udí na trhu práce a napokon štvrtá kapitola je zameraná na súčasné výzvy vo vzdelávaní mladých l'udí. 


\section{Teoretické a empirické prístupy k problematike vzdelania $v$ kontexte zamestnanosti a nezamestnanosti}

L’udský kapitál je „súhrn schopností a vedomostí, ktorými l’udia disponujú.“ (Alexy, 2009, s.13) Friedman zaviedol pojem l'udský kapitál do ekonómie, pričom problematiku d'alej rozpracovali ekonómovia chicagskej ekonomickej školy. Kvalita l'udského kapitálu má priamy odraz vo vzdelaní a v procese učenia sa, pričom ekonomické subjekty očakávajú výnos z investície do l’udského kapitálu. Podl'a chicagskej školy sa jedná o proces investovania do l'udských schopností, čiže do vzdelania. Výnos predstavuje súkromný úžitok z budúcich vyšších príjmov za kvalifikovanejšiu prácu, lepšie pracovné miesto, prístup k informáciám či spoločenské vzt’ahy. (Brožová, 2003, s. 29) Zhodnotením vzdelania je aktívna pracovná kariéra, ktorá je ale ohrozená $v$ prípade nezamestnanosti, a to najmä dlhodobej, ked'sa ekonomický subjekt dostáva do straty.

Viacero skorších prispievatel'ov k teórii l'udského kapitálu považovalo vzdelávanie spolu so skúsenost'ami ako mechanizmy, ktoré by posilnili schopnost' jednotlivcov pre efektívne rozhodovanie $\mathrm{v}$ meniacich sa podmienkach. K týmto autorom patria napr. Schultz, Fullan, Loubser, Globerman, či Bartel. ( Riddell, Song, 2011)

Brožová (2003, s. 44) vyzdvihuje vzdelanie ako prevenciu proti nezamestnanosti v kontexte vyššej adaptability na meniace sa požiadavky trhu práce. Vznik nových progresívnych odborov v kombinácii stechnologickým pokrokom si vyžaduje špičkové znalosti a otvorenost'. Menej kvalifikovaní pracovníci sú vystavení vyššiemu riziku nezamestnanosti z dôvodu rastu dopytu po vysokokvalifikovaných pracovníkoch a zároveň nižšieho dopytu po menej kvalifikovanej práci. V súvislosti s nezamestnanost'ou je dôležité konštatovanie, že vzdelaný človek vie reagovat' na nové požiadavky trhu práce vo vyššej miere ako nevzdelaný, pričom vie zmysluplne využit' vol'ný čas. Vzdelanie by nemalo byt' zamerané len na pracovné aktivity, ale aj ako ochrana pred nezamestnanost'ou by malo byt' rozvinuté k mimopracovnej sebarealizácii.

Zvyšujúca sa závislost' ekonomiky na informáciách spôsobuje rastúci význam vzdelania pre zabezpečenie uspokojivého zamestnania. Mareš (2002, s. 42) konštatuje, že požiadavky na flexibilitu pracovníkov spolu s rastúcim významom vzdelania má dopad na samotný stav nezamestnanosti. Je potrebná reforma vzdelávacích systémov podporujúcich celoživotné vzdelávanie a rozvoj rekvalifikácie.

Quintini a Martin (2006) v súvislosti s ponímaním vzdelania ako dôležitého faktora výkonnosti jednotlivcov poznamenávajú, že pri viac vzdelaných pracovníkoch je dva až trikrát menšia pravdepodobnost' výskytu nezamestnanosti v porovnaní s osobami s nízkym vzdelaním.

Podl'a teórie implicitných pracovných zmlúv, ktorej predstavitel'mi sú Okun, alebo Azariadis, firmy rozlišujú medzi kvalifikovanými a menej kvalifikovanými pracovníkmi. V súvislosti s ochranou miezd i v čase výkyvov dopytu a s perspektívou rastu príjmu i kariéry, týmto firmy motivujú kvalifikovanejších pracovníkov. Ako prvých tak prepúštajú menej kvalifikovaných pracovníkov, o čom hovorí aj téza „menej kvalifikovaní pracovníci sú najímaní ako poslední a prepúšt’aní ako prví“. (Brožová, 2003, s. 75)

Teória insider - outsider viažuca sa k dlhodobej nezamestnanosti hovorí o nákladoch na dodatočné vzdelanie a nerovnaké podmienky vo vyjednávajúcej sile súčasných zamestnancov a uchádzačov o zamestnanie. Insideri sú súčasní pracovníci, ktorí majú 
výhodnejšie pracovné príležitosti ako outsideri, ktorí sú mimo firmu $z$ dôvodu nezamestnanosti. Ich nerovnost' v sile sa viaže na fluktuáciu pracovnej sily a vznik nákladov na nábor či zaškolenie pracovníkov.

Táto teória bola vyvinutá autormi Lindbeckom a Snowerom od roku 1984 a aplikovaná na nezamestnanost' autormi Blanchardom a Summersom v roku 1986. ( Blanchard, 2006)

Štrukturálne zmeny si dnes vyžadujú získanie novej kvalifikácie, t. j. rekvalifikáciu a zmenu profesie, čo odzrkadl'uje štrukturálnu nezamestnanost' v ekonomike. Brožová (2003, s. 83) uvádza, že v prípade takejto krátkodobej nezamestnanosti ide o tzv. dobrovol'nú nezamestnanost'.

Mareš (2002, s. 21) prináša d'alší pohl'ad na štrukturálnu nezamestnanost' a dáva do pozornosti paradox s ňou spojený. Technologické zmeny, či zmeny výroby spôsobili, že dnes i vysokokvalifikovaní pracovníci určitej profesie sa stali nepotrebnými, a to najmä $\mathrm{v}$ čase prechodu k post industriálnej spoločnosti.

Príprava mládeže pre vstup na pracovný trh spolu s rekvalifikáciou tých osôb, ktoré prišli o zamestnanie vytvára znalosti a zručnosti potrebné $\mathrm{k}$ flexibilite na trhu práce a tým ide o nástroj v boji proti nezamestnanosti. (Kotýnková, 2006, s. 31) Z vyššie uvedeného je zrejmé, že okrem formálneho dosiahnutého vzdelania má svoj význam na trhu práce i d’alšie odborné vzdelávanie a rekvalifikačné kurzy.

Z hl'adiska dosiahnutého vzdelania tzv. signalizačná teória hovorí o vzt'ahu medzi úrovňou vzdelania a vrodenými schopnost’ami človeka. Dosiahnuté vysokoškolské vzdelanie tak signalizuje vyššie schopnosti, adaptabilitu, či motiváciu. Na druhej strane odporcovia tejto teórie uvádzajú, že zamestnávatelia by mali pri výbere pracovníkov používat' testy schopností, a nie sa spoliehat' na vysokoškolské diplomy považované za nákladný spôsob diferencovania pracovníkov na schopných a menej schopných. (Brožová, 2003, s. 39)

Nezamestnanost' v určitej miere negatívne ovplyvňuje aj nepružnost' trhu práce ako dôsledok právnych, zmluvných a inštitucionálnych podmienok. Medzi opatrenia na zníženie tejto nepružnosti patrí aj skvalitňovanie systému vzdelávania a prípravy na povolanie odpovedajúca potrebám trhu práce a vytvorenie systému celoživotného vzdelávania.

Na vzt'ah medzi vzdelaním a nezamestnanost'ou, resp. zamestnanost'ou poukazuje viacero empirických výskumov. Jedným $\mathrm{z}$ nich je štúdia prispievajúca $\mathrm{k}$ línii výskumov odzrkadl'ujúcich pozitívnu koreláciu medzi mierou opätovného zamestnania a dosiahnutým vzdelaním nezamestnaných osôb a taktiež negatívnu koreláciu medzi formálnym vzdelaním a výskytom nezamestnanosti. Autormi sú Riddell a Song (2011), pričom dáta ich štúdie pochádzajú z amerického trhu práce, konkrétne z prieskumu obyvatel'ov (1980-2005) a sčítania obyvatel'ov. Dôležitým aspektom štúdie je, že premenné majú vplyv na dosiahnuté vzdelanie na post-sekundárnej, ako aj sekundárnej úrovni. Záverom štúdie je, že vzdelanie signifikantne zvyšuje mieru opätovného úspešného zamestnania nezamestnaných osôb. Zároveň vzt’ah medzi dosiahnutým vzdelaním a výskytom nezamestnanosti je zmiešaný, nakol'ko na sekundárnej úrovni daný kauzálny vzt’ah nie je, avšak je evidentný pri post sekundárnom vzdelaní, ktoré znižuje výskyt nezamestnanosti.

Súvislost' medzi vzdelaním a nezamestnanost'ou v Európe skúmali v štúdii autori Biagi a Lucifora (2007). Okrem vzdelania skúmali aj faktor demografie. Vychádzali zo skutočnosti, 
že Európske krajiny prešli významnými zmenami $\mathrm{v}$ dosiahnutom vzdelaní $\mathrm{z}$ hl'adiska priemerného počtu rokov vzdelania, ako aj podielu jednotlivcov s vyšším vzdelaním.

Využitím panelových dát v období rokov 1975 - 2002 empiricky testovali edukačné šoky. Výsledky štúdie poukazujú na kvalitatívnu odlišnost' vzdelávacích šokov pre mladých a starších pracovníkov, a taktiež menej a viacej vzdelaných. Zmeny v štruktúre vzdelania znižujú nezamestnanost' viac vzdelaných osôb.

\section{Vývoj situácie mladých l'udí na trhu práce v SR}

Slovenská republika podobne ako d’alšie členské štáty Európskej únie čelia už dlhšiu dobu viacerým problémom v súvislosti s vysokou mierou nezamestnanosti mladých l'udí do 24 rokov a absolventov škôl. Prechod zo školy do zamestnania predstavuje pre túto rizikovú skupinu l'udí, najmä tých, ktorí sú nízko kvalifikovaní, často komplikovaný prelom v ich živote.

Podl'a štúdie OECD za rok 2006 priemerná dížka trvania prechodu zo školy na trh práce je medzi krajinami EÚ odlišná. Medzi krajiny s najdlhším trvaním v roku 2006 patrilo Mad'arsko (3,9 roka), Grécko (3,2 roka), Taliansko (3 roky), Slovensko (2,7 roka) a d'alšie. Naopak, mladým Dánom, Rakúšanom a Holand’anom nájdenie prvého zamestnania trvá $\mathrm{v}$ priemere rok až poldruha roka. (Inštitút pre výskum práce a rodiny, 2011)

V tret'om štvrt'roku 2008, t.j. obdobie, kedy prepukla svetová hospodárska kríza, miera nezamestnanosti mladých l'udí v SR predstavovala 18,8\%. Zhoršenie situácie začalo byt' evidentné až v prvom štvrt'roku 2009 ako dopad krízy, pričom od tohto obdobia sa neustále nezamestnanost' prehlbovala. V priemere sa situácia za celú Európsku úniu zhoršila už v poslednom kvartáli roka 2008, čo predstavovalo zvýšenie nezamestnanosti mladých l'udí na $17 \%$ oproti $15,9 \%$ dosiahnutým v tret'om štvrt'roku 2008.

Celkovo za obdobie rokov 2008 až 2013 sa miera nezamestnanosti mladých l'udí vyšplhala v druhom kvartáli roka 2013 na hodnotu 35,3\%, čo je o 15,2 p. b. viac v porovnaní s druhým štvrt'rokom 2008. Za priemer EÚ nezamestnanost' mladých l'udí vzrástla v roku 2013 o 7,8 p. b. v porovnaní s rokom 2008. Mladí l'udia na Slovensku sú postihnutí mierou nezamestnanosti o 12,1 p. b. vyššou v II. kvartáli roka 2013 ako je priemer EÚ.

Z obrázku 1 vyplýva, že pri porovnávaní údajov za druhý štvrt'rok 2007 - 2013 najnižšiu mieru nezamestnanosti mladých l'udí v SR zaznamenávame v druhom kvartáli roka 2008 s hodnotou 20,1\%, čo je zlepšenie o 0,4 p.b. oproti II. štvrt'roku 2007.

Obrázok 1: Porovnanie miery nezamestnanosti mladých l’udí vo veku 15 - 24 rokov v SR s priemerom EÚ 27 v období 2. štvrt'rokov 2007 až 2013

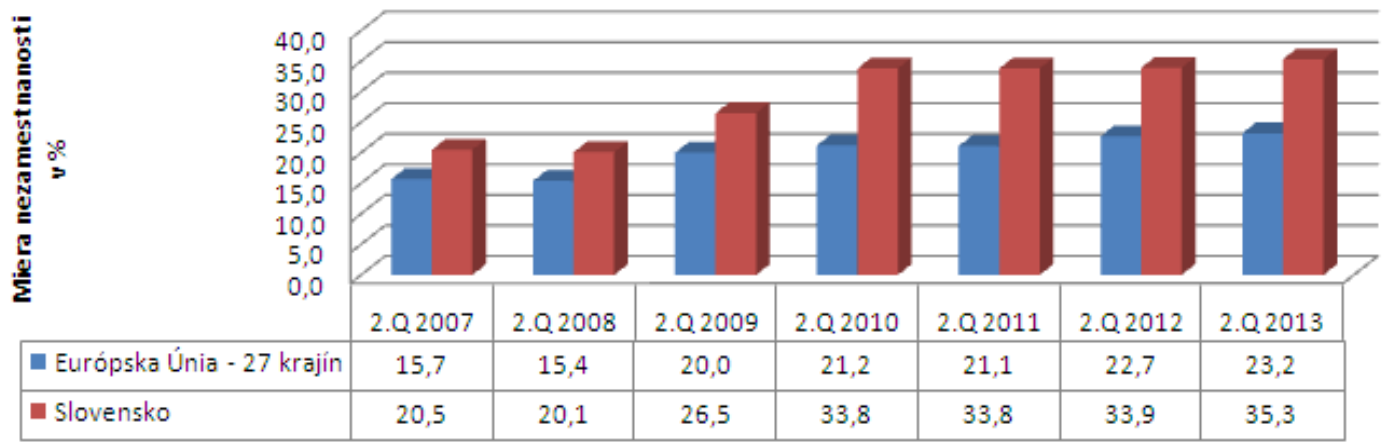

Zdroj: vlastné spracovanie podl'a údajov z Eurostatu 
Z hl'adiska dosiahnutého stupňa vzdelania v SR bolo v prvom štvrt'roku 2013 najviac nezamestnaných l'udí do 24 rokov so základným vzdelaním s mierou nezamestnanosti 59,7\%. V porovnaní s ostatnými krajinami EÚ dosiahlo vyššie percento Španielsko a Chorvátsko, a približne rovnaké percento Grécko, konkrétne 59\%.

Miera nezamestnanosti mladých so stredoškolským a pomaturitným kvalifikačným neterciárnym vzdelaním dosiahla úroveň $32,1 \%$. Pri týchto osobách bola miera nezamestnanosti v prvom štvrt'roku 2013 jednou z najvyšších v EÚ. Osoby 15 - 24 ročné s vysokoškolským vzdelaním dosiahli nezamestnanost' $27 \%$, pričom sa jedná o pokles oproti poslednému štvrt'roku 2012 o 8,7 p.b.

Tabul'ka 1: Miera nezamestnanosti 15 - 24 ročných z hl'adiska dosiahnutého vzdelania podl'a európskeho hodnotenia vzdelania ISCED v členských štátoch EÚ v prvom štvrt'roku $2013^{1}$

\begin{tabular}{|c|c|c|c|c|}
\hline $\begin{array}{c}\text { Krajina/Stupeň } \\
\text { vzdelania }\end{array}$ & $\begin{array}{c}\text { Predprimárne, } \\
\text { primárne a nižšie } \\
\text { sekundárne vzdelanie } \\
\text { /ISCED 0-2/ }\end{array}$ & $\begin{array}{c}\text { Vyššie sekundárne, } \\
\text { post-sekundárne } \\
\text { neterciárne vzdelanie } \\
\text { /ISCED 3-4/ }\end{array}$ & $\begin{array}{c}\text { Prvý a druhý stupeň } \\
\text { terciárneho } \\
\text { vzdelania } \\
\text { /ISCED 5-6/ }\end{array}$ & $\begin{array}{c}\text { Všetky } \\
\text { stupne } \\
\text { vzdelania }\end{array}$ \\
\hline Belgicko & 40,7 & 20,5 & 12,4 & 23,3 \\
\hline Bulharsko & 54,4 & 26,6 & $:$ & 29,5 \\
\hline Česká republika & 45,4 & 16,5 & 10,9 & 19,2 \\
\hline Dánsko & 15,6 & 11.3 & $:$ & 13,5 \\
\hline Nemecko & 10,8 & 6,2 & : & 7,8 \\
\hline Estónsko & & 24,0 & $:$ & 23,1 \\
\hline Írsko & 41,7 & 27,2 & 15,5 & 26,7 \\
\hline Grécko & 59,0 & 62,7 & 51,1 & 60,0 \\
\hline Španielsko & 65,0 & 51,6 & 44,8 & 57,2 \\
\hline Francúzsko & $:$ & : & : & \\
\hline Taliansko & 46,3 & 40,1 & 38,1 & 41,9 \\
\hline Cyprus & 48,5 & 34,8 & 36,3 & 37,5 \\
\hline Lotyšsko & 41,0 & 18,5 & $:$ & 22,2 \\
\hline Litva & 41 & 22,5 & $:$ & 22,7 \\
\hline Luxembursko & 25,3 & 12,0 & $:$ & 19,6 \\
\hline Mad'arsko & 54,7 & 26,8 & 19,6 & 30,5 \\
\hline Malta & 23,0 & $:$ & $:$ & 12,2 \\
\hline Holandsko & 14,6 & 8,6 & 6,3 & 11,1 \\
\hline Rakúsko & 12,9 & 7,7 & $:$ & 9,3 \\
\hline Pol'sko & 37,9 & 28,5 & 25,3 & 29,2 \\
\hline Portugalsko & 43,8 & 39,3 & 45,1 & 42,1 \\
\hline Krajina & /ISCED 0-2/ & /ISCED 3-4/ & /ISCED 5-6/ & Spolu \\
\hline Rumunsko & 17,1 & 26,1 & 30,6 & 23,8 \\
\hline Slovinsko & 30,8 & 21,2 & 25,7 & 23,3 \\
\hline Slovensko $^{2}$ & 59,7 & 32,1 & 27,0 & 34,4 \\
\hline Fínsko & 33,8 & 17,3 & $:$ & 22,4 \\
\hline Švédsko & 44,9 & 20,3 & 18,2 & 26,6 \\
\hline Spojené král’ovstvo & 34,9 & 19,1 & 10,6 & 20,1 \\
\hline Chorvátsko & 77,3 & 57,4 & 66,4 & 59,0 \\
\hline
\end{tabular}

Zdroj: vlastné spracovanie využitím údajov z Eurostatu

\footnotetext{
${ }^{1}$ ISCED - skratka pre názov The International Standard Classification of Education

${ }^{2} \mathrm{~V}$ slovenskej školskej sústave ISCED 0 - materská škola, ISCED 1 - 1. stupeň základnej školy, ISCED 2- 2. stupeň základnej školy a nižšie ročníky osemročných gymnázií, ISCED 3 - stredné školy s maturitou, bez maturity, ISCED 4 - pomaturitné kvalifikačné vzdelanie, ISCED 5 - vyššie odborné vzdelanie, I. a II. Stupeň VŠ, ISCED 6 - Doktorandské štúdium
} 


\section{Význam vzdelávania pri uplatňovaní mladých l'udí na trhu práce}

V súčasnosti sa čoraz viac prehlbuje dôležitost' vzdelávania v súvislosti s poskytovaním správnych zručností pre zamestnatel'nost', zvýšenie efektívnosti inštitúcií vzdelávania a odbornej prípravy, či zlepšenie spolupráce so zainteresovanými stranami. V SR neustále dlhodobo pretrváva problém neflexibilného prispôsobovania zručností pre požiadavky trhu práce. Vzdelávanie je jednou z oblastí, ktoré sa výrazne podiel'a na budúcom uplatňovaní mladých l'udí, absolventov na trhu práce. Vo viacerých krajinách EÚ samotné vzdelávacie systémy sú súčast'ou integrovanej stratégie pre zabezpečenie flexibility a istoty v rovnakom čase na trhu práce, t.j. flexiistoty.

Vzdelávanie sa v dnešnej znalostnej spoločnosti stáva celoživotným procesom i pre mladých l'udí, ktorí práve vo veku cca. 18 až 25 rokov prechádzajú zo školy na trh práce v závislosti od získania stredoškolského, resp. vysokoškolského vzdelávania. Školské vzdelávanie vo vzdelávacej sústave SR, podobne ako v d'alších krajinách, je súčast'ou celoživotného vzdelávania. Podl'a Eurostatu ide aj o tzv. formálne vzdelávanie definované ako „,vzdelávanie poskytované v systéme škôl, vysokých škôl, univerzít a v d’alších formálnych vzdelávacích inštitúciách, ktoré normálne poskytujú denné vzdelávanie detí a mládeže všeobecne začínajúcich vo veku pät' až sedem rokov a pokračujúcich až do veku 20 alebo 25 rokov." (Eurydice, 2011)

Potreba nepretržitého získavania nových vedomostí, zručností a znalostí však pokračuje i po získaní určitého stupňa vzdelania, resp. mnohokrát je potrebná i popri študovaní v systéme formálneho vzdelávania. Ide o d’alšie vzdelávanie ako súčast' celoživotného vzdelávania. Zákon č. 568/2009 Z. z. o celoživotnom vzdelávaní ho definuje ako vzdelávanie nadväzujúce na stupeň vzdelania dosiahnutý v školskom vzdelávaní.“ Uskutočňuje sa v inštitúciách d'alšieho vzdelávania, kde je možné získat' čiastočnú alebo úplnú kvalifikáciu, doplnit', prehĺbit' obnovit' či rozšírit' existujúcu kvalifikáciu nadobudnutú v školskom vzdelávaní. Stupeň vzdelania nie je možné získat' absolvovaním d’alšieho vzdelávania. ${ }^{3}$

Medzi druhy d'alšieho vzdelávania zarad'ujeme nasledovné: ${ }^{4}$

- d'alšie odborné vzdelávanie v akreditovanom vzdelávacom programe,

- rekvalifikačné vzdelávanie, ktoré vedie k získaniu čiastočnej kvalifikácie alebo k získaniu úplnej kvalifikácie,

- kontinuálne vzdelávanie vo vzdelávacích programoch, ktorým si účastník d'alšieho vzdelávania doplňuje, rozširuje, prehlbuje alebo obnovuje kvalifikáciu,

- záujmové vzdelávanie, občianske vzdelávanie, vzdelávanie seniorov a iné vzdelávanie.

Ide o tzv. neformálne vzdelávanie, ktoré je definované ako „každá organizovaná a podporovaná vzdelávacia činnost', ktorá presne nekorešponduje $\mathrm{s}$ definíciou formálneho vzdelávania." Môže sa konat' vo vzdelávacích inštitúciách, aj mimo nich a môže byt' poskytované osobám všetkých vekových skupín. (Eurydice, 2011)

\section{Súčasné výzvy vo vzdelávaní mladých l’udí a potreba zvyšovania ich zamestnatel’nosti a zamestnanosti}

$\mathrm{Na}$ Slovensku je nad’alej náročná tranzícia zo školy do zamestnania, pričom systém vzdelávania nereaguje pohotovo na požiadavky trhu práce, aj napriek reformným opatreniam

\footnotetext{
${ }^{3}$ Zákon č. 568/2009 Z. z. o celoživotnom vzdelávaní a o zmene a doplnení niektorých zákonov.

${ }^{4}$ Zákon č. 568/2009 Z. z. o celoživotnom vzdelávaní a o zmene a doplnení niektorých zákonov.
} 
v roku 2012 zameraným na zlepšenie kvality a relevantnosti vzdelávania pre potreby trhu práce. Kvantita je uprednostňovaná pred kvalitou financovania vzdelávania, ktoré je nastavené $v$ prepočte na jedného študenta a zároveň sa vynakladá menej prostriedkov na samotných pedagógov, materiály a vybavenie pre výučbu. Nie úplne vyhovujúca je spolupráca medzi vysokými školami a súkromným sektorom. (Európska komisia, 2013)

V novembri 2012 Európska Komisia vydala oznámenie Európskemu parlamentu, Rade, Európskemu hospodárskemu a sociálnemu výboru a výboru regiónov, zamerané na potrebu prehodnotenia vzdelávania. Medzi hlavné oblasti a výzvy zabezpečenia investícií do zručností patria nasledovné: (Európska komisia, 2012a)

- rozvíjanie prierezových zručností, nadobudnutie základných poznatkov a zručností, osobitná pozornost' pri učení jazykov, zvyšovanie kvality odborných zručností,

- intenzívnejšia spolupráca na európskej úrovni, podporovanie európskej mobility a cezhraničné uznávanie kvalifikácií,

- prijatie opatrení na podporu nových postupov vo výučbe a v štúdiu, zlepšenie kvality vysokoškolského vzdelávania,

- posilnenie partnerstva škôl a súkromného sektora,

- intenzívnejšie využívanie informačných a komunikačných technológií vo vzdelávaní.

Ďalším dôležitým krokom Európskej komisie bola v decembri roka 2012 reakcia na žiadost' Európskej rady a parlamentu návrhom opatrení na riešenie situácie mladých l’udí v balíku opatrení. Balík opatrení zahŕňa odporúčania pre členské štáty EÚ pre zavedenie záruk pre mladých l'udí s ciel'om zabezpečit', aby všetci l'udia vo veku do 25 rokov mohli získat' kvalitnú ponuku zamestnania, d’alšie vzdelávanie, vyučenie alebo stáže v lehote štyroch mesiacov od ukončenia formálneho vzdelávania alebo od straty zamestnania. Je potrebné, aby členské štáty nadviazali silnú spoluprácu s firmami a ostatnými partnermi, ktorí podporujú mladých, zabezpečili skoré intervencie, týkajúce sa služieb zamestnanosti, prijali podporné opatrenia zabezpečujúce pracovné začlenenie, plne využívali na tento účel Európsky sociálny fond a d'alšie štrukturálne fondy, hodnotili a zlepšovali systémy záruk pre mladých a rýchlo implementovali navrhované schémy.

Je dôležité vyzdvihnút', že pre možnosti získavania vysoko kvalitných pracovných skúseností formou pracovných stáži budú uskutočňované konzultácie s Európskymi sociálnymi partnermi. V súvislosti s učebnými odbormi bude ich kvalitu vylepšovat' Európska aliancia pre učňovské odbory, čo taktiež pomôže v odstraňovaní prekážok mobility mladých l'udí.

V oznámení Európskej Komisie z decembra 2012 pod názvom „Dostat' mladých do zamestnania“" sa okrem systému záruk vzhl'adom na pretrvávajúce problémy situácie mladých v EÚ zarad’ujú nasledovné opatrenia: (Európska komisia, 2012b)

- prijatie odporúčaní pre jednotlivé krajiny v rámci európskeho semestra,

- posilnit' finančné nástroje EÚ na mobilitu mladých v rámci Únie - konzultácie o programe pracovných miest EURES pre mladých l'udí,

- prijatie krokov pre podporu kvalitných stáží a učňovskej prípravy - Komisia začína druhú fázu konzultácií so sociálnymi partnermi, založí Európske združenie učňovskej prípravy. Stáže sa čoraz viac javia ako potrebné získanie odborných skúseností v praxi a mladými l'ud'mi sú považované za súčast' ich pracovnej kariéry. Prinášajú vel'ké množstvo výhod 
tak pre študentov, resp. absolventov, ako aj samotné firmy. Vel'ký význam majú i medzinárodné stáže, pri ktorých ich účastníci zdokonal'ujú i cudzí jazyk, čo im následne otvára nové možnosti pri ich budúcom stálom zamestnaní v rámci Európskej únie, či d’alších krajín. V súčasnosti však chýbajú usmernenia pre kvalitu rozvoja medzinárodných stáží.

V prípade učňovského vzdelávania, inak nazvaným duálnym vzdelávaním prostredníctvom pracovných skúseností v podniku na základe pracovnej zmluvy a zároveň prepojených teoretických vedomostí prostredníctvom vzdelávacej inštitúcie, tieto systémy pomáhajú ul'ahčit' prechod zo školy do zamestnania.

Vhodným príkladom učňovského vzdelávania je Rakúsko, kde vzdelávanie učňov zabezpečované podnikmi je doplnené o povinnú účast' na odbornom vzdelávaní v školách. Učni môžu byt' vyškolení v rozsahu právne uznávaných učňovských remesiel. Po ukončení povinnej školskej dochádzky začne v súčasnosti 40\% mladých l’udí učňovské vzdelávanie. $40 \%$ učňov v týchto školách zostane po získaní vzdelania pracovat' u daného zamestnávatel'a a zhruba 40000 podnikov zaškolí 120000 učňov.

Učňovské vzdelávanie trvá od dvoch po štyri roky. Spoločnosti poskytujúce vzdelávanie pre učňov sú povinné poskytovat' zručnosti a know - how v rámci odborného profilu, čo zaist'uje jednotný minimálny štandard vzdelávania. $\mathrm{Na}$ druhú stranu najmä malé podniky, ktoré nie sú schopné zabezpečit' celý odborný profil, môžu poskytovat' doplnkové vzdelávanie a tréningy, čím aj svojím dielom prispievajú k učňovskému vzdelávaniu. Štúdium v reálnom prostredí má mnoho výhod, napríklad získavanie sociálnych schopností, či schopností riešit' problémy. Hlavnou výhodou, ktorá priamo súvisí so zamestnanost'ou mladých l'udí je skutočnost', že študent môže byt' po ukončení učňovského vzdelávania zamestnaný d'alej v spoločnosti na trvalý pracovný pomer. ( Bundesministerium für bildung und frauen, 2014)

Ďalším medzníkom pri riešení nezamestnanosti mladých bolo oznámenie s názvom „Spoločne pre mladých l'udí Európy“ vydané Európskou komisiou v júni 2013, ktoré predstavuje výzvu na prijatie opatrení proti nezamestnanosti mládeže.

V odporúčaní pre SR z mája 2013, ktoré sa týka národného programu reforiem Slovenska na rok 2013, a ktorým sa predkladá stanovisko Rady k programu stability Slovenska na roky 2012 - 2016 sa zdôrazňujú viaceré skutočnosti týkajúce sa trhu práce a mladých l’udí v predchádzajúcom období.

Aktivity, ktoré majú prispiet' $\mathrm{k}$ riešeniu nezamestnanosti mladých l'udí a absolventov škôl sú naplánované $\mathrm{v}$ rámci akčného plánu reforiem, ktorý je súčast'ou národného programu reforiem. Zarad'ujeme sem tieto opatrenia: (Vláda SR, 2013)

- Národný projekt „Rozvoj stredného odborného vzdelávania“ z prostriedkov štrukturálnych fondov EÚ, ktorým sa má zabezpečit' spolupráca so zamestnávatel'mi a zamestnávatel'skými zväzmi v rámci systému odborného vzdelávania a prípravy. Žiaci by mali vykonávat'odbornú prax priamo vo firmách.

- Národný projekt "Národná sústava kvalifikácií“" z prostriedkov štrukturálnych fondov EÚ- úlohou je posilnit' kvalitu odborného vzdelávania $\mathrm{v}$ odboroch, $\mathrm{v}$ odboroch, ktoré sú požadované trhom práce definovaním výsledkov vzdelávania a zaradením do úrovní kvalifikačného rámca. Projekt sa nachádza v štádiu realizácie, pričom termín splnenia je október 2015. 
- Národný projekt „Dielne praktického výcviku“ z prostriedkov štrukturálnych fondov EÚ - ciel’om je podporovanie nadobudnutia odborného vzdelania a praxe vo vybraných odboroch.

- Reforma normatívneho financovania pre regionálne školstvo s ciel'om dat' dôraz na uplatnenie absolventov na trhu práce a na náročnost' štúdia. Termín splnenia reformnej úlohy je december 2013.

- „Tvorba vnútorných systémov zabezpečovania kvality poskytovaného vysokoškolského vzdelávania, reforma akreditácie a sprísnenie kritérií pre získanie titulov profesor a docent. Úloha je čiastočne splnená s termínom do decembra 2013.“

- Legislatívna úprava uznávania výsledkov neformálneho vzdelávania, ktorá umožní nadobudnutie novej kvalifikácie prostredníctvom predošlej praxe alebo d'alšieho vzdelávania. Úloha je čiastočne splnená s termínom do decembra 2014.

- Podpora kariérového poradenstva pre dospelých v rámci národného projektu „Ďalšie vzdelávanie a poradenstvo pre dospelých“".

- Rozvoj technických odborov na VŠ so zameraním na zvýšenie kvality týchto odborov a adekvátne technické vybavenie s predpokladaným ukončením na jeseň 2014.

- Podpora zamestnanosti mladých prostredníctvom projektov na podporu vzniku pracovných miest vo verejnom aj súkromnom sektore.

- Akčný plán pre mládež na roky 2012-2013 prijatý v októbri 2012. Obsahuje 7 opatrení zameraných najmä na kvalitu a význam vzdelávania vrátane odborného vzdelávania a prípravy.

- Zavedenie modifikácie absolventskej praxe novelou zákonu o službách zamestnanosti prijatou v marci roka 2013 s ciel'om posilnit' odbornost' absolventov škôl pri praktických skúsenostiach.

- Systém stimulov pre mladých je súčast'ou novely zákona o službách zamestnanosti. Je určený pre mladých l'udí s nízkou kvalifikáciou, ktorého zámerom je zvýšenie vlastnej iniciatívy mladých l'udí zúčastňovat' sa vzdelávania a prípravy pre trh práce.

- Prepojenie vzdelania a trhu práce, ktoré zdôrazňuje novela zákona o službách zamestnanosti. V rámci tejto úlohy sú naplánované národné a dopytovo orientované projekty.

- Príprava a prijatie systému záruk pre mladých l'udí do 25 rokov do konca roku 2013.

- Národná sústava povolaní pre „identifikáciu sektorovej potreby zručností na trhu práce a dopytu po kvalifikovanej pracovnej sile“. Predpokladaný plán ukončenia úlohy je koniec roka 2014.

- Opatrenia na zlepšenie podnikatel'ského prostredia a MSP.

Záver

Viacero ekonómov sa $\mathrm{v}$ teórii, ako aj v empirických výskumoch zaoberajú vzt’ahom medzi vzdelaním a nezamestnanost'ou, resp. zamestnanost'ou a konštatujú pozitívny vplyv vyššieho vzdelania na postavenie subjektov na trhu práce.

V Slovenskej republike sa situácia mladých l’udí na trhu práce vyvíja nepriaznivým trendom, čomu zodpovedá aj dlhotrvajúca vysoká nezamestnanost' mladých l'udí. Celkovo za obdobie rokov 2008 až 2013 sa miera nezamestnanosti mladých l'udí vyšplhala v druhom kvartáli roka 2013 na hodnotu 35,3\%, čo je o 15,2 p. b. viac v porovnaní s druhým štvrt'rokom 2008. 
Slovensko patrí taktiež ku krajinám s najdlhším trvaním prechodu zo školy na trh práce, pričom podl'a OECD prechod trval v roku 2006 až 2,7 roka.

Pre ul'ahčenie prechod zo školy do zamestnania, získanie kvalitného zamestnania v rámci vyštudovaného odboru, či možnosti uplatnit' sa v zahraničí je v súčasnom turbulentnom prostredí je dôležitá aktuálnost' ponúkaných zručností, vedomostí a znalostí. Školský systém by mal byt' flexibilný a zároveň by mal zabezpečovat' mladým l'udom určité istoty.

Medzi strategické smery a ciele $\mathrm{v}$ oblasti vzdelávania vytýčené Európskou úniou patria „Zvýšenie kvality a efektivity vzdelávacích systémov členských štátov, ul'ahčenie všetkým občanom prístup k vzdelávaniu a otvorenie vzdelávacích systémov širšiemu svetu.“

Z odporúčaní pre SR z mája 2013 vyplývajú pre Slovenskú republiku návrhy ako riešit' nepriaznivú situáciu mladých prostredníctvom Záruk pre mladých, prijat' opatrenia s ciel'om zlepšit' výsledky vzdelávania, $\mathrm{v}$ odbornom vzdelávaní a príprave posilnit' poskytovanie praktickej výučby priamo v podnikoch, či podporit' účinné odovzdávanie znalostí podporou spolupráce medzi vysokými školami, výskumnou komunitou a podnikatel'ských sektorom.

V súčasnosti v SR vystupuje do popredia potreba vel'kej novely odborného vzdelávania, ktorá by mala byt' pripravená v prvom polroku 2014. Prvé kroky vedúce k zmene v odbornom vzdelávaní boli iniciované v rámci medzinárodnej konferencie na tému Odborné vzdelávanie - možnosti transferu a implementácie prvkov duálneho vzdelávacieho systému, kde svoje skúsenosti z fungovania duálneho systému vzdelávania priniesli zástupcovia Nemecka, Rakúska, ale aj Českej republiky a Mad'arska. Úspešné duálne systémy odbornej prípravy, najmä v Rakúsku a Nemecku, sú vhodnou inšpiráciou aj pre slovenský trh práce.

\section{Pod'akovanie}

Príspevok vznikol v rámci riešenia projektu VEGA č. 1/0112/13 „Etablovanie a perspektívy rozvoja konceptu sociálnej ekonomiky $\mathrm{v}$ kontexte prebiehajúcich sociálno-ekonomických zmien na Slovensku“.

\section{Literatúra}

[1] Akčný plán národného programu reforiem. Vláda SR [online]. [vid. 10. 08. 2013] Dostupné na: http://ec.europa.eu/europe2020/pdf/nd/nrpactplan2013_slovakia_sk.pdf.

[2] ALEXY, J., 2009. Trh práce a manažment l'udských zdrojov. Bratislava: Ekonóm. ISBN 978-80-1'728-6.

[3] BIAGI, F. and C. LUCIFORA, 2007. Demographic and education effects on unemployment in Europe. Labour Economics [online]. 2. 10. 2007 [vid. 31.5.2014]. Dostupné na: http://www.sciencedirect.com/science/article/pii/S0927537107000929

[4] BLANCHARD, O., 2006. European unemployment: the evolution of facts and ideas. Economic Policy, 45(21), 5-59. ISSN 1468-0327.

[5] BROŽOVÁ, D., 2003. Společenské souvislosti trhu práce. Praha: Sociologické nakladatelství. ISBN 80-86429-16-4.

[6] BUNDESMINISTERIUM FÜR BILDUNG UND FRAUEN, 2014. Apprenticeship Training in Austria, The Dual System [online]. 26.05.2014 [vid. 3. 09. 2014] Dostupné na: https://www.bmbf.gv.at/enfr/school/secon/app.html 
[7] Dospelí vo formálnom vzdelávaní: politika a prax v Európe, 2011. Brusel: Eurydice. ISBN 978-92-9201-174-1

[8] Dostat' mladých do zamestnania, 2012. Európska komisia [online]. [vid. 14.08. 2013] Dostupné na: http://eur-lex.europa.eu/LexUriServ/LexUriServ.do?uri= COM:2012:0727:FIN:SK:HTML

[9] KOTÝNKOVÁ, M., 2006. Trh práce na přelomu tisíciletí. Praha: Nakladatelství Oeconomica. ISBN 80-245-1149-5.

[10] MAREŠ, P., 2002. Nezaměstnanost jako sociální problém. Praha: Sociologické nakladatelství. ISBN 80-86429-08-3.

[11] Odporúčania rady, ktoré sa týka národného programu reforiem Slovenska na rok 2013 a ktorým sa predkladá stanovisko Rady k programu stability Slovenska na roky 20122016, 2013. Európska komisia [online]. 29. 05. 2013 [vid. 11. 08. 2013]. Dostupné na: http://ec.europa.eu/europe2020/pdf/nd/csr2013_slovakia_sk.pdf

[12] Prehodnotenie vzdelávania: investície do zručností na dosiahnutie lepších sociálnoekonomických výsledkov, 2012. Európska komisia [online]. 20.11 .2012 [vid. 25. 08. 2013]. Dostupné na: http://eur-lex.europa.eu/LexUriServ/ LexUriServ.do?uri=COM:2012:0669:FIN:EN:PDF

[13] Prechod zo školy na trh práce: konceptuálny rámec a indikátory, 2011. Inštitút pre výskum práce a rodiny [online]. Jún 2011 [vid. 13. 08. 2013]. Dostupné na: http://www.sspr.gov.sk/IVPR/images/IVPR/bulletin/Bulletin-3-2011.pdf

[14] QUINTINI, G. and S. MARTIN, 2006. Starting Well or Losing their way? The Position of Youth in the Labour Market in OECD countries. DELSA Working Paper OECD [online]. OECD [vid. 22. 02. 2013]. Dostupné na: http://www.oecd.org/employment/emp 137805131.pdf

[15] RIDDELL, C. W. and X. SONG, 2011. The impact of education on unemployment incidence and reemployment success: Evidence from the U.S. labour market. Labour Economics [online]. 22.1.2011. [vid. 30.5.2014]. Dostupné na: http://www.sciencedirect.com/science/article/pii/S0927537111000054

[16] Zákon č. 568/2009 Z. z. o celoživotnom vzdelávaní a o zmene a doplnení niektorých zákonov [online]. [vid. 10. 09. 2013] Dostupné na: http://jaspi.justice.gov.sk/jaspiw1/htm _zak/jaspiw_mini_zak_zobraz_clanok1.asp?kotva=k1\&skupina=1 